\title{
Efficient Protein Expression and Virus-Induced Gene Silencing in Plants Using a Crinivirus-Derived Vector
}

\author{
Wenjie Qiao (i) and Bryce W. Falk* \\ Department of Plant Pathology, University of California, Davis, 95616 CA, USA; qwenjie@ucdavis.edu \\ * Correspondence: bwfalk@ucdavis.edu; Tel.: +1-530-752-0302
}

Received: 8 April 2018; Accepted: 21 April 2018; Published: 24 April 2018

\begin{abstract}
Plant virus-based vectors are valuable tools for recombinant gene expression and functional genomics for both basic and applied research. In this study, Lettuce infectious yellows virus (LIYV) of the genus Crinivirus was engineered into a virus vector that is applicable for efficient protein expression and virus-induced gene silencing (VIGS) in plants. We examined gene replacement and "add a gene" strategies to develop LIYV-derived vectors for transient expression of the green fluorescent protein (GFP) reporter in Nicotiana benthamiana plants. The latter yielded higher GFP expression and was further examined by testing the effects of heterologous controller elements (CEs). A series of five vector constructs with progressively extended LIYV CP sgRNA CEs were tested, the longest CE gave the highest GFP expression but lower virus accumulation. The whitefly transmissibility of the optimized vector construct to other host plants, and the capability to accommodate and express a larger gene, a $1.8 \mathrm{~kb} \beta$-glucuronidase (GUS) gene, were confirmed. Furthermore, the LIYV vector was also validated VIGS by silencing the endogenous gene, phytoene desaturase (PDS) in N. benthamiana plants, and the transgene GFP in N. benthamiana line 16c plants. Therefore, LIYV-derived vectors could provide a technical reference for developing vectors of other economically important criniviruses.
\end{abstract}

Keywords: Crinivirus; Lettuce infectious yellows virus; protein expression; virus-induced gene silencing

\section{Introduction}

Plant virus-based vectors are important tools for gene expression and silencing in plants, and have been widely applied for both fundamental and applied research including tracking virus movement and distribution in plants [1-3], examining gene/protein functions by over-expression or silencing [4-7], triggering RNA interference (RNAi)-mediated plant protection against pathogens or insects [8-12], and producing commercial products such as enzymes, immunogens or antibodies [13-17]. As a convenient laboratory tool for molecular research and as an alternative to generating transgenic plants for various purposes, many RNA and DNA plant viruses with different host ranges have been engineered and the list is still growing [3,18-20].

Criniviruses, the whitefly-transmitted members in the family Closteroviridae, cause phloem-limited infections in various important crops worldwide such as lettuce, tomato, cucurbits, and sweet potato, that lead to severe diseases and significant economic losses [21]. Viruses in the genus Crinivirus are characterized by their large bipartite genome of positive-sense single-stranded RNA totaling approximately $15.3-17.7 \mathrm{~kb}$. The overall genomic organization is similar for all viruses in the genus, Lettuce infectious yellows virus (LIYV) is the type member [22]. LIYV RNA1 is $8118 \mathrm{nt}$ and encodes proteins associated with replication and alone is competent for replication: ORFs $1 \mathrm{a}$ and $1 \mathrm{~b}$ code for the conserved domains of papain-like cysteine proteinase (PRO), methyltransferase (MTR), helicase (HEL) and RNA-dependent RNA polymerase (RdRp), P34 encoded by ORF2 is translated from its subgenomic RNA (sgRNA) and is required for LIYV RNA2 replication [23,24]. RNA2 is $7193 \mathrm{nt}$ and contains seven ORFs encoding proteins relevant to virion encapsidation, movement and vector 
transmission: the CP (major coat protein), CPm (minor coat protein), Hsp70h, and P59 are virion structural components, only CPm can be partially deleted and retain systemic infection in plants but shows disrupted whitefly transmissibility [25,26]; P26 induces plasmalemma deposit and is required for systemic plant infection [27]; two remaining small proteins, P5 and P9, are two nonstructural proteins not required for systemic infection, although when deleted, both showed alleviated LIYV symptoms and decreased virus accumulation levels in plants. P5 is likely translated directly from genomic RNA2, while six 3'-coterminal sgRNAs produced from RNA2 serve as mRNAs for the remaining six genes and their expression is regulated by the cis-acting sequences located immediately upstream of their ORFs, referred as 'controller elements' (CE) [28,29].

So far, for viruses of the Closteroviridae, only three viruses, all of the genus Closterovirus, have been developed as virus vectors. These have proved to be useful for fundamental and translational studies, but all have relatively limited plant host ranges. By contrast, LIYV has a relatively wide host range among herbaceous plant species, and unlike viruses of the genus Closterovirus, criniviruses such as LIYV have 2 genomic RNAs and shorter virions, thus offering different opportunities as a virus-based expression vector. In this work, we examined strategies for constructing a LIYV-based vector for transient reporter expression in plants utilizing the green fluorescent protein (GFP) and $\beta$-glucuronidase (GUS) genes, thus facilitating gene expression quantification and the monitoring the virus infection progress. We also assessed whether the LIYV-based vector might be useful as a tool for virus induced gene silencing (VIGS) to knock-down target gene expression through RNA interference (RNAi) for conveying gene functions [30-32]. Here, we showed that LIYV can be used both for recombinant protein expression and as a VIGS vector, and that the recombinant virus retains whitefly vector transmissibility allowing for testing in various plant species.

\section{Materials and Methods}

\subsection{Plant Materials}

The HC-Pro transgenic Nicotiana benthamiana plants overexpressing the silencing suppressor P1/HC-Pro of Turnip mosaic virus were commonly used in this study to enhance LIYV accumulation and symptom development [10]. The 16c transgenic N. benthamiana plants expressing GFP were used to test the effects of LIYV-VIGS construct [33]. Seeds from both transgenic plants were germinated on KCMS medium containing kanamycin antibiotic $(50 \mathrm{mg} / \mathrm{mL})$, after transplanting onto soil, they were kept in growth chamber with $24^{\circ} \mathrm{C}$ constant temperature, $60 \%$ humidity and $16 / 8$ h daylight cycle. Lettuce (Lactuca sativa L.) and Chenopodium murale plants were kept in greenhouse at $20-25^{\circ} \mathrm{C}$ with $14 \mathrm{~h}$ light period.

\subsection{LIYV Constructs}

The full-length cDNA clones of LIYV-WT were the basis of all constructs in this study (Figure 1) [10]. All the constructs were generated through one or two steps using In-Fusion HD Cloning Kit following manufacturer's instructions (Clontech, Mountain View, CA, USA), and all the plasmid backbones or insertion sequences needed were amplified using CloneAmp HiFi PCR Premix (Clontech). For creating constructs by gene insertion, the ORFs of cycle 3 GFP (a GFP mutant with improved brightness and eliminated tendency to aggregate [34,35]) and GUS, or the truncated PDS and GFP sequences were first cloned into LIYV RNA1 or RNA2 clones, followed by introducing the CE sequence selected in front of CP genes of LIYV (Accession \# U15441, 4071-4220 nt), BYV (Accession \# AF190581, 13,547-13,641 nt; [36]) and CYSDV (Accession \# FJ492808, 4777-4926 nt). To generate the P5 substitution construct, the GFP ORF was simply ligated into the linearized plasmid of LIYV RNA2 clone without the P5 ORF through In-Fusion Cloning. All clones were sequenced to verify the accuracy of insertions prior to further analysis. 
A.
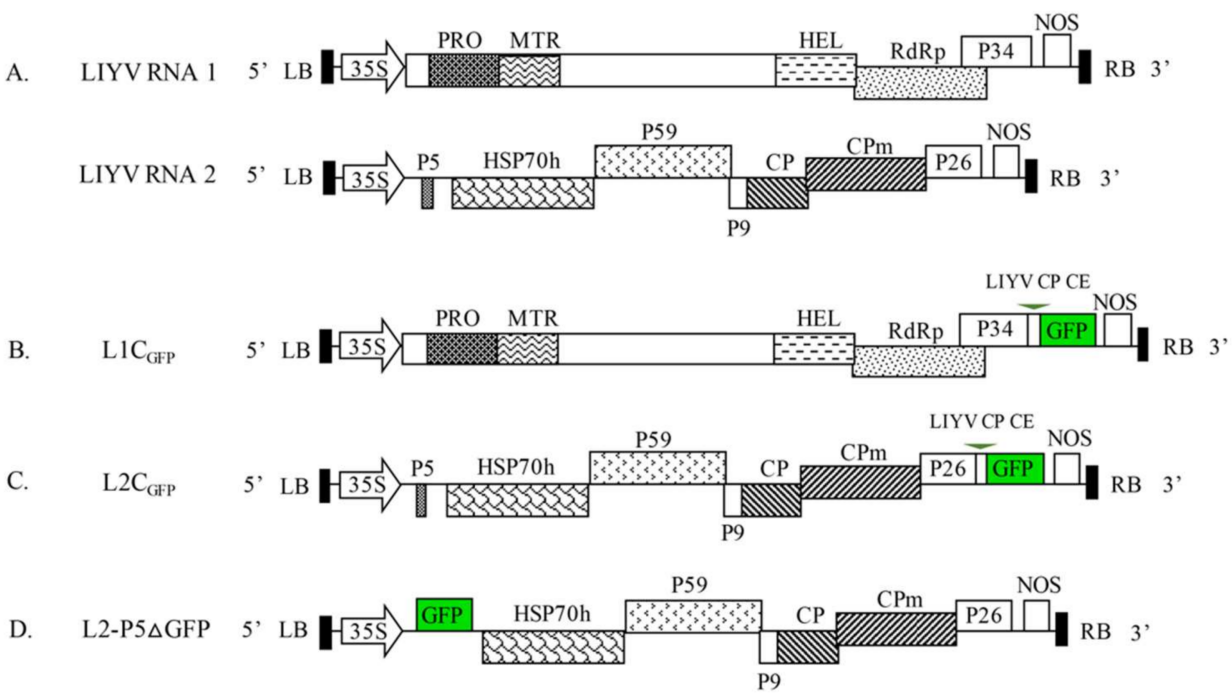

Figure 1. Schematic diagram of the genome organization of lettuce infectious yellows virus (LIYV) cDNA infectious clones (A), and their derivatives encoding green fluorescent protein (GFP): (B) L1C GFP $_{\text {, }}$ the GFP ORF under a duplicated LIYV CP subgenomic RNA controller element (LIYV CP CE) inserted between P34 ORF and 3'-nontranslated region (NTR) of LIYV RNA1; (C) L2 $\mathrm{C}_{\mathrm{GFP}}$, the GFP ORF under a duplicated LIYV CP CE inserted between P26 ORF and 3'NTR of LIYV RNA2; (D) L2-P5 $\triangle$ GFP, the P5 gene of LIYV RNA2 replaced by the GFP ORF. LB, left border; RB, right border; 35S, 35S promoter; NOS, nopaline synthase terminator; the boxes indicate open reading frames (ORF) and their corresponding translation products: PRO, papain-like cysteine proteinase; MTR, methyltransferase; HEL, helicase; POL, RNA-dependent RNA polymerase; HSP70h, heat shock protein 70 homolog; $\mathrm{CP}$, capsid protein; $\mathrm{CPm}$, minor capsid protein; $\mathrm{P}$, proteins named by their approximate molecular mass (e.g., P34, 34-kDa protein).

\subsection{LIYV Inoculation}

LIYV constructs were delivered to the target plants by agroinoculation or whitefly (Bemisia tabaci) transmission. For N. benthamiana plants, LIYV constructs were transformed into Agrobacterium tumefaciens (strain GV3101) and agroinfiltrated into plants at 4-6 leaf stages as described before [10]. For lettuce and C. murale plants, LIYV virions were purified from systemically infected $N$. benthamiana plants following the protocol described by Klaassen, et al. [37]. After a 6 to $10 \mathrm{~h}$ acquisition period on an artificial sucrose diet containing LIYV particles, the viruliferous B. tabaci were transferred onto six young lettuce plants and six C. murale plants for virus inoculation [25]. Whiteflies were eliminated with insecticide after a three-day inoculation access period.

\subsection{Fluorescence Detection}

GFP fluorescence of the whole plants or the intact leaves and flowers was viewed with a long-wavelength UV light and was photographed directly using a Canon EOS 600D digital camera. Images of fluorescence distribution in hand-cut cross and longitudinal sections of petioles and roots from LIYV-L2 $\mathrm{C}_{\mathrm{GFP}}$ infected $N$. benthamiana plants were taken with a Leica MZFIII fluorescence stereomicroscope (Leica Microsystems, Wetzlar, Germany) provided with UV illumination and a GFP filter. To observe the magnified leaf veinlets, the epidermal cells were removed from the lower side of leaf tissue and mounted in water. GFP fluorescence was observed using a Leica DM5000 B fluorescence microscope (Leica Microsystems).

\section{5. $R T-P C R$ and $R T-q P C R$}

For RT-PCR and real-time RT-qPCR, total RNAs were extracted from upper non-inoculated leaves using the TRIzol reagent (Invitrogen, Carlsbad, CA, USA) and treated with DNase 
(QIAGEN, Hilden, Germany) to remove contaminating DNA. Systemic infection and foreign gene stability were checked by RT-PCR, the first-strand cDNAs were generated with SuperScript ${ }^{\mathrm{TM}}$ II Reverse Transcriptase (Invitrogen), and PCR was carried out to amplify the partial LIYV CP-coding region (530 bp) using the primer set LIYV-CP_F (5'-TTGTCCAAAATCGTTGTACGCG-3') and LIYV-CP_R (5'-CCACCTTCACCTTTGCATAATG-3'). For all the "add a gene" constructs of LIYV RNA2, the insertions were checked with primers flanking the inserted segment, LIYV-IN_F (5'-CACGATCTCTCCTTTAGATAAGCAAAGG-3') and LIYV-IN_R (5'-ATCGAATAATTCAATCACCACTCTCTGATCA-3').

For real-time RT-qPCR to determine the viral RNA accumulation level, cDNA synthesis was performed with iScript reverse transcription supermix (Bio-Rad, Hercules, CA, USA), and real-time qPCR reactions were assembled with iTaq universal probes supermix (Bio-Rad), the relative LIYV RNA accumulation level was determined using RNA1-specific primers LIYV RNA1_F (5'-TGTTCGCCCAGGT-TAGATTTG-3'), LIYV RNA1_R (5'-TTCACCATATCCTTTCAGCCC-3') and LIYV RNA1_Probe (5'-AGACACATCCAAAGGGCCACAGT-3'), the $N$. benthamiana protein phosphatase 2A (PP2A) transcripts quantified with PP2A_F: 5'-GAGAAAACCATTCGCCCTAGT-3', PP2A_R: 5'-GACTGAAGTGCTTGATTGGC-3 ${ }^{\prime}$ and PP2A_Probe: $5^{\prime}$-CTGAAGACCCTGATGTTGATGTTCGCT- $3^{\prime}$ was used as an internal control. QPCR was performed and analyzed with a CFX96 real-time PCR detection system (Bio-Rad) following the manufacturer's recommendations.

\subsection{Immunoblot Analysis}

Immunoblot analysis was employed to confirm successful LIYV infection and GFP accumulation. Total proteins of $0.1 \mathrm{~g}$ plant material were extracted in $100 \mathrm{mM}$ Tris- $\mathrm{HCl}$ (pH 7.5), $100 \mathrm{mM}$ EDTA ( $\mathrm{pH}$ 8.0), $5 \mathrm{mM}$ dithiothreitol, $150 \mathrm{mM} \mathrm{NaCl}$, and $0.1 \%(v / v)$ Triton $\mathrm{X}-100$, separated by SDS-PAGE, and transferred to nitrocellulose membranes [38]. LIYV CP and exogenous GFP protein were detected by immunoblotting using LIYV CP and GFP specific antibodies produced in rabbit. Horseradish peroxidase-coupled goat anti-rabbit IgG (Bio-Rad) was used as the secondary antibody. The blots were treated with chemiluminescence detection reagents (Thermo, Waltham, MA, USA) for visualization.

\subsection{GUS Assays}

GUS histochemical staining was performed on N. benthamiana leaves and hand-cut sections of petioles and stems using assays modified from Lagarde et al. [39]. In brief, plant tissues were vacuum infiltrated with GUS staining buffer comprising $50 \mathrm{mM}$ sodium phosphate ( $\mathrm{pH} 7.0), 10 \mathrm{mM}$ EDTA $(\mathrm{pH} 8.0), 0.1 \%(v / v)$ Triton X-100, $0.5 \mathrm{mg} / \mathrm{mL}$ X-Gluc. The enzymatic reaction was performed at $37^{\circ} \mathrm{C}$ overnight in the dark. Tissue pigments were removed through a graded ethanol series. The GUS activity was viewed and directly photographed.

\section{Results}

\subsection{Addition of the GFP Gene to the LIYV Genome}

The "add-a-gene" strategy, i.e., engineering of an autonomous expression cassette controlled by an additional sgRNA promoter or CE, is preferred in developing closterovirus-based vectors for stable and high-level expression [40]. Genes placed closer to the $3^{\prime}$ terminus of the closterovirus genomic RNA tend to be expressed in greater amounts [36]. Therefore, for the bipartite LIYV genome, we inserted a GFP expression cassette, including the GFP ORF and a homologous duplication of $150 \mathrm{nt}$ upstream of the LIYV CP ORF as the sgRNA CE, into the LIYV infectious cDNA clones. The cassette was inserted between the P34 ORF and $3^{\prime}$-nontranslated region (NTR) of RNA1, and between the P26 ORF and 3'NTR of RNA2, referred to as L1C $\mathrm{GFP}_{\mathrm{GFP}}$ and $\mathrm{L}_{2} \mathrm{C}_{\mathrm{GFP}}$ respectively (Figure 1). The combinations of the wild-type RNA1/RNA2 (LIYV-WT), L1C GFP /RNA2 (LIYV-L1C $_{\text {GFP) }}$ ) and RNA1/L2 $\mathrm{C}_{\mathrm{GFP}}$ (LIYV-L2 $\mathrm{C}_{\mathrm{GFP}}$ ) were delivered respectively to Hc-Pro transgenic $N$. benthamiana plants by agroinfiltration. At 3 weeks post inoculation (wpi), typical LIYV symptoms were observed in 
LIYV-L2 $\mathrm{C}_{\mathrm{GFP}}$ inoculated plants, although these appeared milder and about one week later than symptoms caused by LIYV-WT (Figure 2A). The GFP fluorescence was observed in LIYV-L2C $\mathrm{C}_{\text {GFP }}$ infected plants by using a handheld long-wave UV light, the brightest fluorescence was in areas that showed typical LIYV-induced leaf yellowing (Figure 2B). However, no viral symptoms or GFP

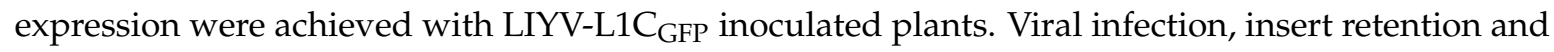
GFP accumulation from LIYV-L2 $\mathrm{C}_{\mathrm{GFP}}$ in upper leaves were confirmed by RT-PCR with primers amplifying the sequences of LIYV CP and the GFP expression cassette, and by immunoblot analysis using antibodies specific to LIYV CP and GFP (Figure 2C,D). LIYV RNA accumulation was quantified by RT-qPCR, consistent with symptom severity, LIYV RNA titer was almost twice higher in LIYV-WT infected plants than that in LIYV-L2 $\mathrm{C}_{\mathrm{GFP}}$ infected plants (Figure 2E). LIYV-L2C $\mathrm{GFP}_{\mathrm{GFP}}$ distribution in tissues of systemically infected $N$. benthamiana plants was monitored by fluorescence microscopy. GFP fluorescence initially ( 2 to $3 \mathrm{wpi}$ ) showed in stems and was unevenly distributed limited to the main veins or veinlets of medium and upper leaves. After another 1 to 2 weeks, GFP fluorescence appeared brighter in the leaves but remained phloem-limited. This was revealed by the bright fluorescence observed in leaves, leaf petioles, roots and flowers of $N$. benthamiana plants (Figure 2F).

\subsection{Substitution of an LIYV ORF with the GFP ORF}

Another common way to construct viral vectors for foreign protein expression is to substitute a viral gene that is not necessary for replication and movement with the gene for the desired protein. LIYV only has two genes encoded by RNA2, P5 and P9, that can be eliminated without disrupting systemic infection in $N$. benthamiana plants, but these mutations lead to decreased symptoms and virus accumulation. P5 is encoded by the first ORF of LIYV RNA2, while P9 ORF is positioned near the middle of RNA 2 with its $5^{\prime}$-terminus overlapping the P59 gene and its $3^{\prime}$-terminus $3 \mathrm{nt}$ away from CP ORF. Considering the complexity of the location of P9 ORF, we chose to replace the P5 ORF with the GFP ORF, resulting in construct L2-P5 $\triangle$ GFP. When A. tumefaciens harboring L2-P5 $\Delta$ GFP was co-infiltrated with the wild-type RNA1 into Hc-Pro N. benthamiana plants, GFP expression was observed in upper non-inoculated leaves under UV light along with the development of LIYV symptoms, however, the fluorescence was much weaker than that of LIYV-L2 $\mathrm{C}_{\mathrm{GFP}}$ at the same infection stage (Figure 3A). The systemic infection of LIYV-L2-P5 $\triangle$ GFP was confirmed by RT-PCR with total RNA isolated from upper leaves using LIYV CP primers, while the presence of the GFP cassette was determined using primers flanking the original P5 ORF. The expected PCR products of $282 \mathrm{bp}$ for LIYV-WT and $882 \mathrm{bp}$ for LIYV-L2-P5 $\triangle$ GFP were detected (Figure 3B). LIYV CP and GFP accumulation levels in LIYV-L2-P5 $\Delta$ GFP infected plants were further determined by immunoblot analysis, both

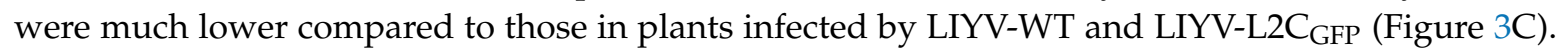
These results demonstrated that GFP expression can be achieved by substituting LIYV P5 ORF with GFP ORF but at a lower efficiency comparing with the "add-a-gene" construct LIYV-L2 $\mathrm{C}_{\mathrm{GFP}}$. 

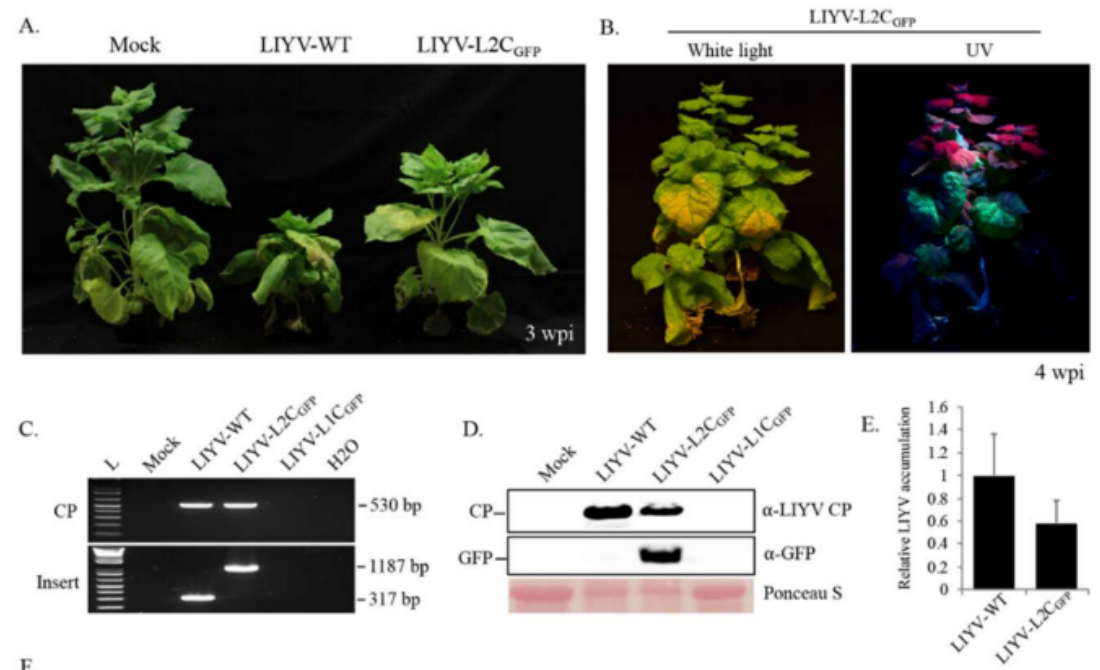

F.

UV Fluorescence microscopy

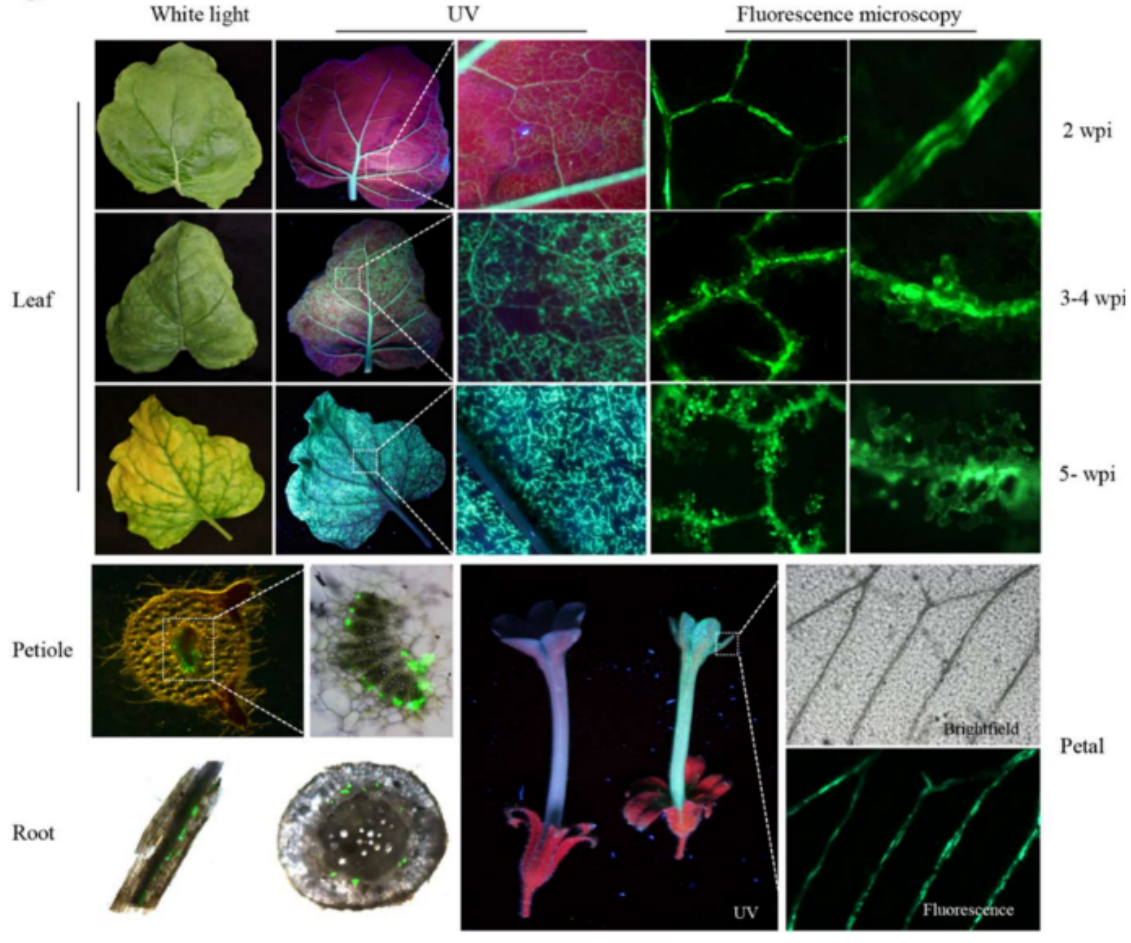

Figure 2. Viral infection and GFP expression of LIYV-based "add-a-gene" expression vectors in Hc-Pro Nicotiana benthamiana plants. (A) Phenotypes of LIYV-WT and LIYV-L2C $\mathrm{GFP}_{\text {infected }}$ $N$. benthamiana plants photographed at 3 weeks post inoculation. Mock indicates buffer-inoculated control. (B) LIYV-L2 $\mathrm{C}_{\mathrm{GFP}}$ infected N. benthamiana plant photographed under white and UV light. (C) Detection of viral infection and insertion integrity by RT-PCR with total RNA extracted from upper non-inoculated leaves of LIYV-WT, LIYV-L1C $\mathrm{GFP}_{\mathrm{G}}$, and LIYV-L2 $\mathrm{C}_{\mathrm{GFP}}$ agroinoculated plants. Two primer sets were used to amplify the sequence of LIYV CP (CP, $530 \mathrm{bp})$ and the sequence flanking the GFP cassette (Insert, $1187 \mathrm{bp}$ ), LIYV-WT without the insert was amplified as a control (317 bp). (D) Immunoblot analysis of LIYV CP and GFP accumulation in upper non-inoculated leaves using LIYV CP and GFP specific antibodies. The Ponceau $S$ stained rubisco large subunit serves as a loading

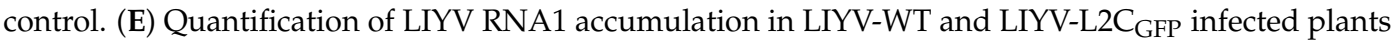
by RT-qPCR. The PP2A transcript level of N. benthamiana was used as an internal control. Error bars denote standard errors from at least three biological replicates. (F) Systemic spread and distribution in leaves, petioles, roots and flowers of LIYV-L2 $\mathrm{C}_{\mathrm{GFP}}$ infected plants monitored by GFP fluorescence. Leaf, progress of LIYV infection and accumulation along veins over time. GFP fluorescence was visualized under UV light and fluorescence microscopy with different magnification. GFP was confined to vascular tissues of petiole, root (left, root segment; right, root cross-section), and petal was seen under UV light and fluorescence microscopy. Dotted lines indicate enlarged areas. 
A.
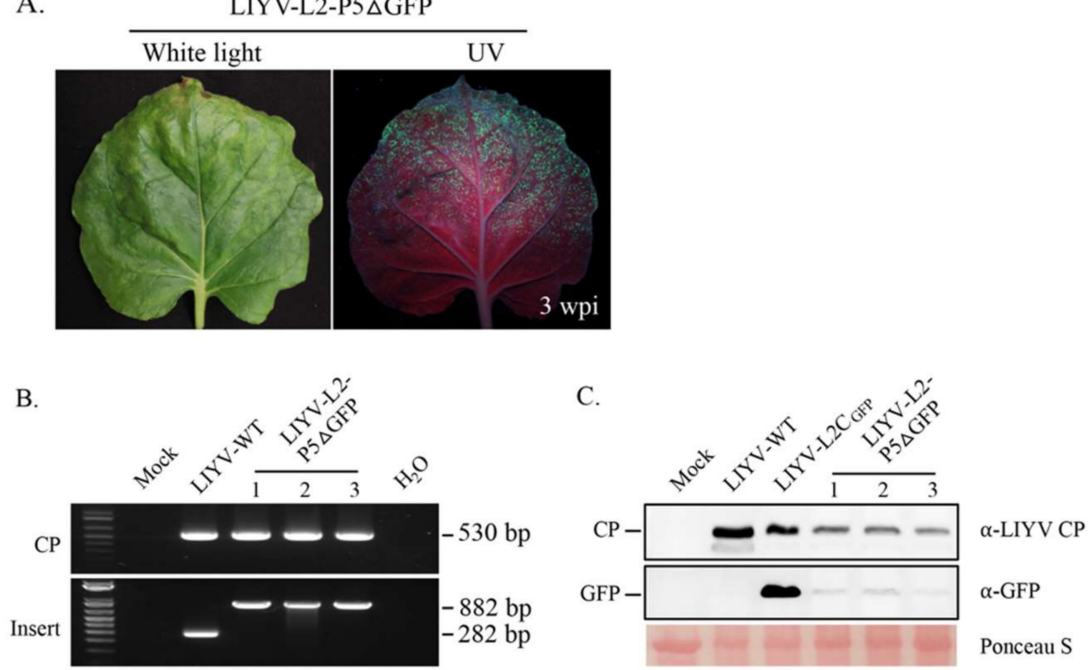

Figure 3. Viral infection and GFP expression of LIYV-based "ORF substitution" expression vector in Hc-Pro Nicotiana benthamiana plants. (A) LIYV symptoms in upper non-inoculated leaves of LIYV-L2-P5 $\Delta$ GFP infected plants at 3 wpi and GFP fluorescence visualized under UV light. (B) Detection of viral infection and insertion integrity by RT-PCR using total RNA extracted from upper non-inoculated leaves of LIYV-WT and LIYV-L2-P5 $\triangle$ GFP agroinoculated plants. Two primer sets were used to amplify the sequence of LIYV CP (CP, $530 \mathrm{bp}$ ) and the sequence flanking the GFP ORF (Insert, $882 \mathrm{bp}$ ), LIYV-WT without the GFP ORF was used as a control (282 bp). (C) Immunoblot analysis of LIYV CP and GFP accumulation in upper non-inoculated leaves infected by LIYV-WT, LIYV-L2C GFP, $_{\text {, }}$ and LIYV-L2-P5 $\triangle$ GFP using LIYV CP and GFP specific antibodies. The Ponceau S stained rubisco large subunit serves as a loading control.

\subsection{Effects of Heterologous CP CES}

Duplication of the sgRNA CE has been found to cause homologous recombination resulting in the loss of the inserted sequences, while the use of a heterologous sgRNA CE from related viruses were relatively stable [41]. To determine whether this was also the case for LIYV, the homologous duplication of the $150 \mathrm{nt}$ LIYV CP sgRNA CE in $\mathrm{L}_{2} \mathrm{C}_{\mathrm{GFP}}$ was replaced by the heterologous CP sgRNA $\mathrm{CE}$ of Beet yellows virus (BYV, genus Closterovirus) and Cucurbit yellowing stunting disorder virus (CYSDV, genus Crinivirus), assembled as $\mathrm{BC}_{\mathrm{GFP}}$ and $\mathrm{CC}_{\mathrm{GFP}}$. A tumefaciens cells harboring these constructs together with the wild-type LIYV RNA1 clone were infiltrated into leaves of Hc-Pro N. benthamiana plants and symptom development and GFP expression were monitored over time. LIYV symptoms

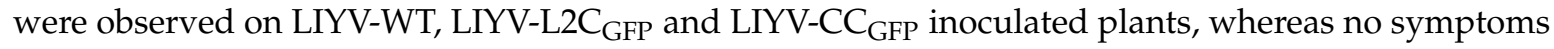
of infection were seen for the LIYV-BC $\mathrm{GFP}_{\mathrm{GP}}$ construct (Figure $4 \mathrm{~A}$ ). Surprisingly, the GFP fluorescence was only detected for LIYV-L2 $C_{\text {GFP }}$ infected plants under the UV light (Figure 4A). Systemic infection and protein expression were confirmed by RT-PCR and immunoblot analysis. Consistent with the symptom development, the sequences of LIYV CP and the inserted cassette were detected within upper non-inoculated leaves of LIYV-WT, LIYV-L2 $\mathrm{C}_{\mathrm{GFP}}$ and LIYV-CC $\mathrm{GFP}_{\mathrm{infected}}$ plants, indicating systemic infection of these constructs and integrity of the insertions, and no LIYV RNA was detected

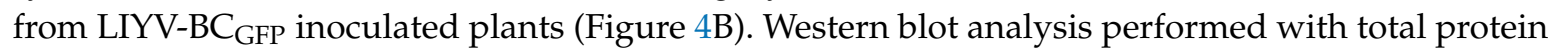
extracts from agroinoculated and upper non-inoculated leaves showed that both LIYV CP and GFP were detected in LIYV-L2 $\mathrm{C}_{\mathrm{GFP}}$ infected leaf samples, and although a similar CP expression level was

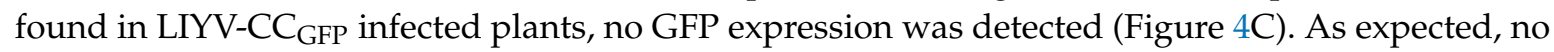
LIYV infection was detected with LIYV-BC ${ }_{\mathrm{GFP}}$ inoculated plants. 


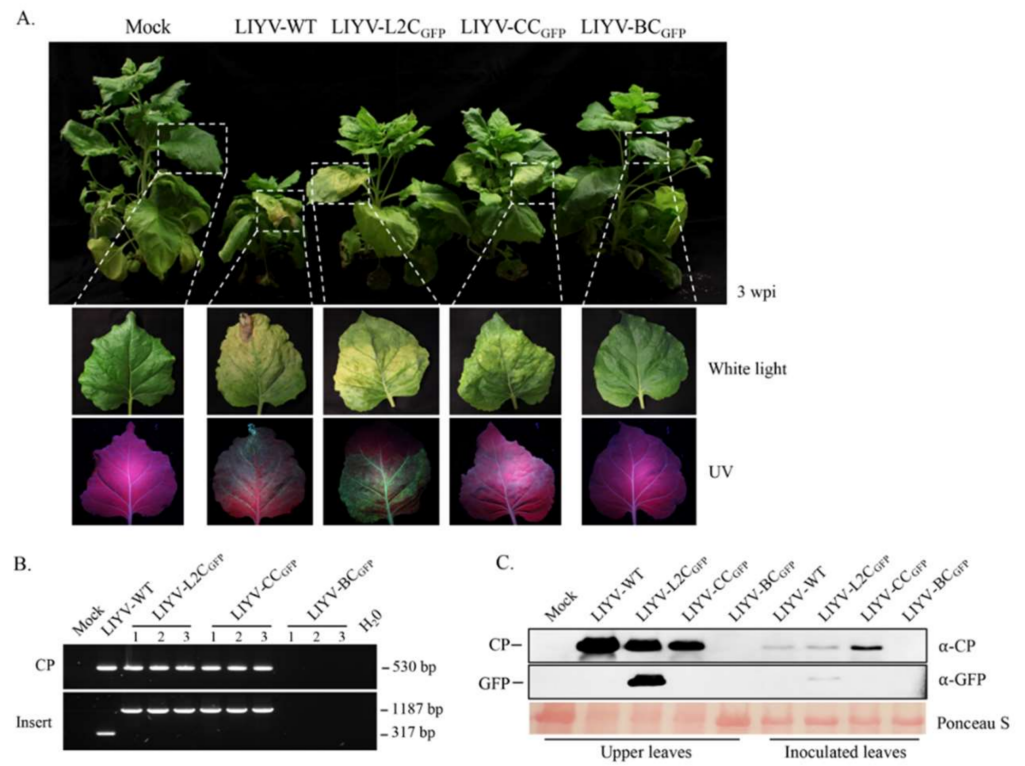

Figure 4. Effects of heterologous CP subgenomic controller elements (CEs) on LIYV infection and GFP expression in Hc-Pro Nicotiana benthamiana plants. (A) Phenotypes of N. benthamiana plants

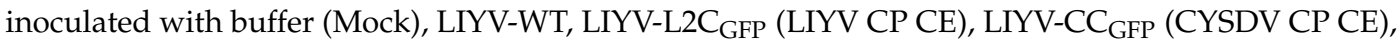
and LIYV-BC $\mathrm{GFP}_{\mathrm{G}}$ (BYV CP CE) at 3 wpi. Symptoms on upper leaves (white light) and GFP fluorescence visualized under UV light (lower panels). Dotted lines indicate enlarged areas. (B) Detection of viral infection and insertion integrity by RT-PCR with total RNA extracted from upper non-inoculated leaves. Two primer sets were used to amplify the sequence of LIYV CP (CP, $530 \mathrm{bp})$ and the sequence flanking the GFP cassette (Insert, $1187 \mathrm{bp}$ ), LIYV-WT without the insert was amplified as a control (317 bp). (C) Immunoblot analysis of LIYV CP and GFP accumulation with total protein extracts from agroinoculated and upper non-inoculated leaves using LIYV CP and GFP specific antibodies. The Ponceau S stained rubisco large subunit serves as a loading control.

\subsection{Effects of the Size of LIYV CP CE}

The $150 \mathrm{nt}$ CE sequence for LIYV-L2 $\mathrm{C}_{\mathrm{GFP}}$ was first selected as an arbitrary sequence upstream of the LIYV CP ORF. To examine the effects of different lengths of this upstream sequence, another four constructs ranging from 50-250 nt inserted in front of the GFP ORF were tested. All five gave systemic infections and GFP expression in agroinoculated Hc-Pro N. benthamiana plants at 2 to 3 wpi. The shortest $50 \mathrm{nt} C E$ insertion construct showed the most severe symptoms but the weakest GFP fluorescence, and decreasing symptom severity and increasing GFP fluorescence were roughly correlated with increasing CE length (Figure 5A). LIYV CP and GFP accumulation were analyzed in systemically infected leaf tissues at 3 wpi and 5 wpi by immunoblot analysis with anti-LIYV CP and anti-GFP antibodies. The $50 \mathrm{nt}$ and $100 \mathrm{nt}$ CE constructs showed high expression of LIYV CP, but reductions of GFP expression, especially at 5 wpi. By contrast, the $200 \mathrm{nt}$ and $250 \mathrm{nt}$ CP CE constructs showed similar CP and GFP accumulation comparable to that of $150 \mathrm{nt}$ CE (Figure 5B). LIYV quantification for these five constructs by RT-qPCR showed a decreasing trend for the viral RNA amount along the increased CE length, consistent with the symptom development and the immunoblot results (Figure 5C). The retention of the inserted GFP cassette was tested over time by RT-PCR, the expected size of the GFP expression cassette was detected in all plants tested, but a few plants showed some very faint bands of lower size at $5 \mathrm{wpi}$, indicating partial deletion of the inserted cassette (Figure 5D). Taken together, these results showed that all the different LIYV CP CE constructs tested were capable of foreign gene expression, however in our experiments the $150 \mathrm{nt}$ was the shortest CE sequence that showed both high GFP expression and LIYV CP accumulation and was most stable 


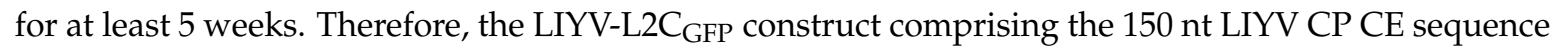
was used for the remaining experiments.

A.

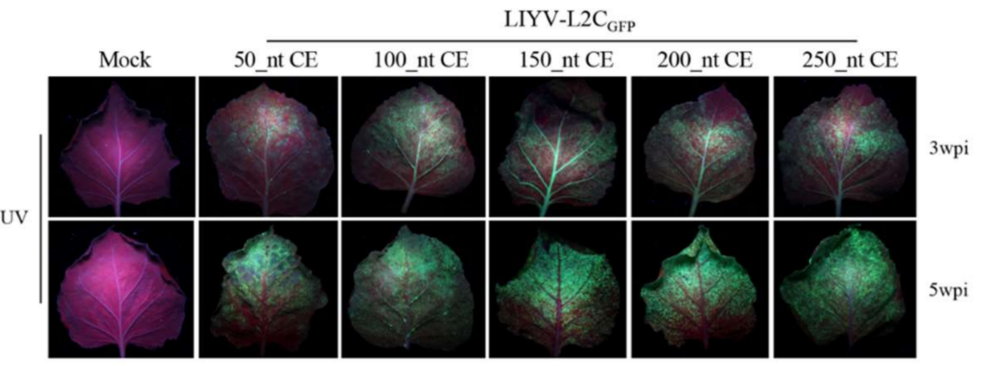

B.
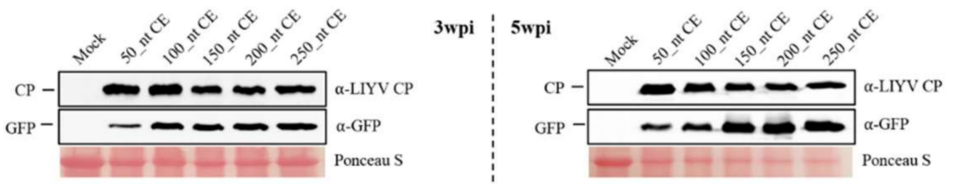

C.

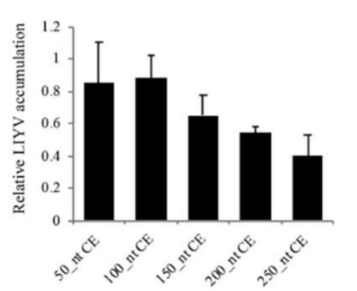

D.
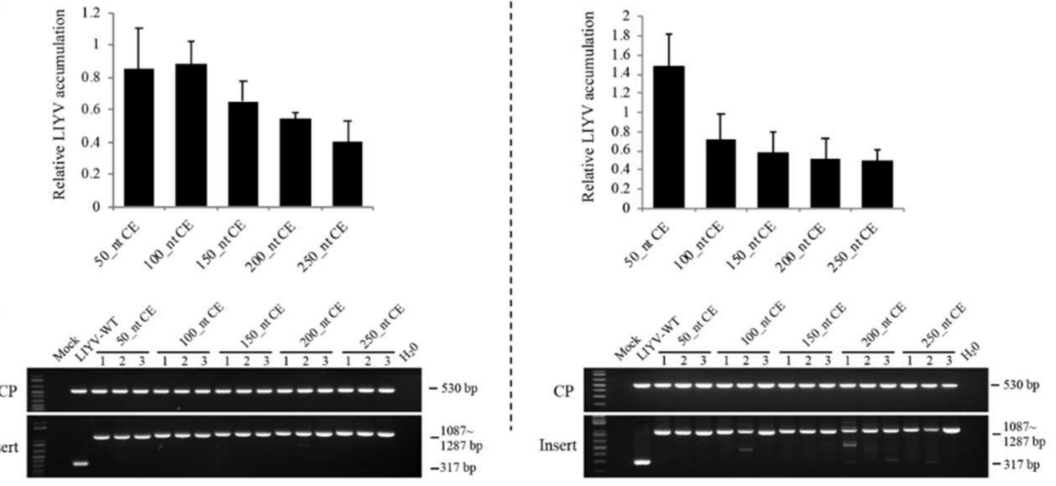

Figure 5. Effects of the size of LIYV CP subgenomic controller element (CE) on viral infection and GFP expression in Hc-Pro Nicotiana benthamiana plants. (A) GFP fluorescence visualized under UV light on upper leaves of $N$. benthamiana plants infected by five LIYV-L2 $\mathrm{C}_{\mathrm{GFP}}$ constructs comprising CP CEs ranging from 50-250 nt at 3 wpi and 5 wpi. (B) Immunoblot analysis of LIYV CP and GFP accumulation with total protein extracts from upper non-inoculated leaves at 3 wpi and 5 wpi using LIYV CP and GFP specific antibodies. The Ponceau S stained Rubisco large subunit serves as a loading control. (C) Quantification of LIYV RNA1 accumulation with total RNA isolated from upper non-inoculated leaves at 3 wpi and 5 wpi through RT-qPCR. The PP2A transcript level of N. benthamiana was used as an internal control. Error bars denote standard errors from at least three biological replicates. (D) Detection of viral infection and insertion integrity by RT-PCR with total RNA extracted from upper non-inoculated leaves at 3 wpi and 5 wpi. Two primer sets were used to amplify the sequence of LIYV CP (CP, $530 \mathrm{bp})$ and the sequence flanking the GFP cassette (Insert, ranging from 1087-1287 bp), LIYV-WT without the insert was amplified as a control (317 bp).

\subsection{Whitefly Transmissibility of LIYV-L2C $G F P$}

Since the agroinoculation system of LIYV infectious clone is only practical for permissive $N$. benthamiana plants, and because LIYV has a wide plant host range, the ability of LIYV-L2C $\mathrm{GFP}$ to be transmitted by its natural vector, the whitefly $B$. tabaci, to other host plants and to express inserted sequences was assessed. B. tabaci do not efficiently feed on N. benthamiana plants and thus cannot acquire LIYV directly from agroinoculated plants, therefore virions were purified from LIYV-L2 $\mathrm{C}_{\mathrm{GFP}}$-agroinoculated plants. Nonviruliferous $B$. tabaci were allowed to feed on a sucrose diet containing purified LIYV-L2C $\mathrm{GFP}_{\mathrm{G}}$ particles, and then transferred to six three-to-four leaf stage lettuce plants (Lactuca sativa L.) and six Chenopodium murale plants for virus inoculation [25]. All plants inoculated by viruliferous $B$. tabaci became infected and showed typical LIYV symptoms 3-4 weeks 
post inoculation (Figure 6). GFP expression was observed in systemically infected lettuce and C. murale plants by exposing plants to UV-light and by fluorescence microscopy (Figure 6). Like for $N$. benthamiana plants, fluorescence was most apparent in older leaves showing typical interveinal yellowing symptoms, and was restricted to veins.

A.

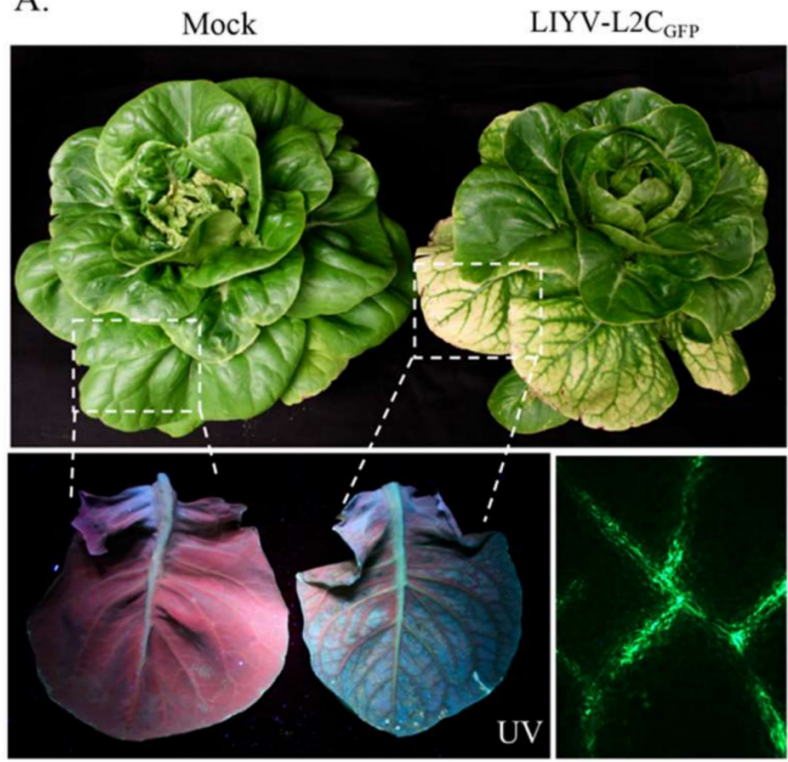

B.
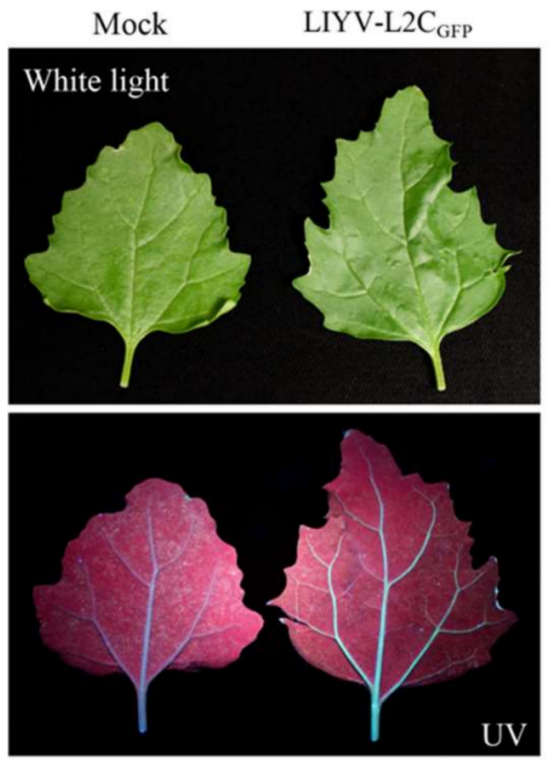

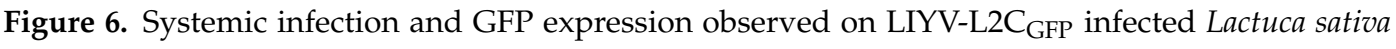
L. and Chenopodium murale plants. Inoculation was performed with Bemisia tabaci that had fed on a sucrose diet containing LIYV-L2 $\mathrm{C}_{\mathrm{GFP}}$ particles purified from infected Nicotiana benthamiana plants. (A) Phenotypes of L. sativa L. plants inoculated with B. tabaci fed with buffer (Mock) and LIYV-L2C $\mathrm{GFP}_{\text {}}$ virions at 3 wpi. GFP fluorescence confined to the vascular tissues was visualized under UV light and fluorescence microscopy (lower panels). Dotted lines indicate enlarged areas. (B) Upper leaves of buffer (Mock) and LIYV-L2 $\mathrm{GFP}_{\mathrm{GF}}$ inoculated C. murale plants photographed under white and UV light. GFP fluorescence was restricted in the veins.

\subsection{Insertion of a Large Gene}

GFP is encoded by a relatively small ORF of only $720 \mathrm{nt}$. Because LIYV virions are rod-shaped filaments, there may not be such severe size restrictions as to the size of sequences that can be inserted into the LIYV genomic RNA2 and still be encapsidated. Therefore, to examine the expression of a larger gene in the LIYV-L2 $\mathrm{C}_{\mathrm{GFP}}$ vector, the $720 \mathrm{nt}$ GFP ORF was replaced with the $1812 \mathrm{nt}$ $\beta$-glucuronidase (GUS) ORF, referred to as LIYV-L2 $\mathrm{C}_{\mathrm{GUS}}$. This construct was tested on Hc-Pro N. benthamiana plants delivered by agroinoculation, LIYV-WT was used as a negative control. Systemic infection was successfully obtained with LIYV-L2 $\mathrm{C}_{\mathrm{GUS}}$, and similar to LIYV-L2 $\mathrm{C}_{\mathrm{GFP}}$, symptoms caused by LIYV-L2C $\mathrm{G}_{\mathrm{GUS}}$ were obvious at ca. 3 wpi, approximately one week later than on LIYV wildtype-infected plants, and symptoms were milder. To test the stability of LIYV-L2 $\mathrm{C}_{\mathrm{GUS}}$, we investigated expression cassette retention over time in $N$. benthamiana plants using RT-PCR with primers for the inserted cassette, primers amplifying the $\mathrm{CP}$ region were used as a control. Total RNA was extracted from the upper non-inoculated leaves of $N$. benthamiana plants infected by LIYV-WT and LIYV-L2C $\mathrm{C}_{\mathrm{GUS}}$ at 3 wpi and 5 wpi. A $2279 \mathrm{bp}$ fragment comprising the complete GUS gene and several by-products of lower size, likely amplified from partially deleted genomes were detected from LIYV-L2 $\mathrm{C}_{\mathrm{GUS}}$ infected plants at $3 \mathrm{wpi}$, while 2 weeks later, only fragments of variant partial deletions were detectable by PCR, indicating the instability of the GUS coding sequence (Figure 7A). However, GUS activity was investigated in intact leaves, petioles and shoots of plants at $3 \mathrm{wpi}$ and $5 \mathrm{wpi}$, and all showed strong GUS signals restricted in the vascular tissues, even at 5 wpi (Figure 7B). 
A.

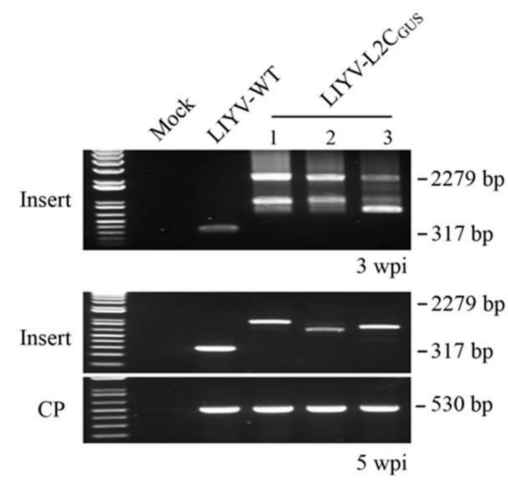

B.

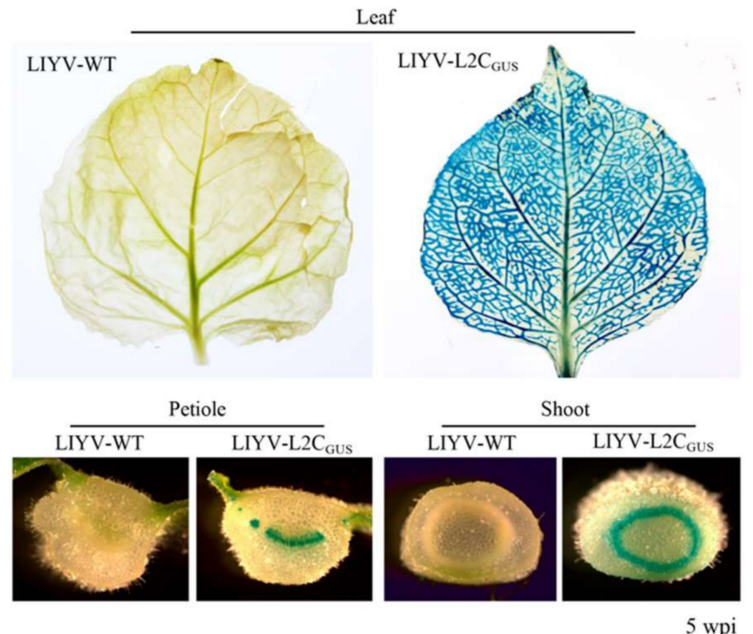

Figure 7. Viral infection and GUS activity in LIYV-L2 $\mathrm{C}_{\mathrm{GUS}}$ inoculated Hc-Pro Nicotiana benthamiana plants. (A) Detection of viral infection and insertion integrity by RT-PCR with total RNA extracted from upper non-inoculated leaves at $3 \mathrm{wpi}$ and $5 \mathrm{wpi}$. Two primer sets were used to amplify the sequence of LIYV CP (CP, $530 \mathrm{bp}$ ) and the sequence flanking the GUS cassette (Insert, $2279 \mathrm{bp}$ ), LIYV-WT without the insert was amplified as a control ( $317 \mathrm{bp})$. The bands in between indicate partial deletions of the GUS cassette. (B) Systemic spread and distribution of GUS activity monitored in intact leaves and the cross-sections of petioles and shoots of LIYV-L2 $\mathrm{C}_{\mathrm{GUS}}$ infected plants at $5 \mathrm{wpi}$. Blue stain indicates GUS activity and was detected only in the vascular tissues. Tissues from LIYV-WT infected plants are applied as a negative control.

\subsection{VIGS in N. benthamiana Plants}

In addition to recombinant protein expression, virus vectors can also be used for VIGS and reverse genetics. To assess the VIGS capabilities of LIYV vector, LIYV-VIGS vectors carrying truncated phytoene desaturase (PDS) and GFP genes were constructed, named as LIYV-L2 $\mathrm{C}_{\mathrm{tPDS}}$ and LIYV-L2 $\mathrm{C}_{\mathrm{tGFP}}$, targeting the endogenous PDS gene of $N$. benthamiana and GFP transgene of $N$. benthamiana line $16 \mathrm{c}$ respectively. We engineered a 559-nt PDS sequence and a 440-nt GFP sequence fragments replacing the GFP ORF of LIYV-L2 $\mathrm{C}_{\mathrm{GFP}}$ respectively under LIYV CP CE. A photo-bleaching phenotype in the vascular tissues of the newly emerged leaves was observed in LIYV-L2 $\mathrm{C}_{\mathrm{tPDS}}$ agroinoculated Hc-Pro $N$. benthamiana plants at ca. 3 wpi. RT-PCR-based analysis for retention of the inserted sequence showed good retention at $3 \mathrm{wpi}$, but instability of the insertion was observed at $5 \mathrm{wpi}$ (Figure 8A).

The LIYV-L2 $\mathrm{C}_{\mathrm{tGFP}}$ construct was also tested on transgenic $16 \mathrm{c}$ N. benthamiana plants expressing GFP. The progress of GFP silencing was monitored using a long-wave UV lamp. Loss of fluorescence due to LIYV-VIGS was obvious by ca. 2 wpi, mostly along the veins of the agroinfiltrated plants. VIGS based silencing expanded into other areas gradually over time (Figure 8B), verifying the mobility of RNAi signal as described for Arabidopsis [42,43]. Systemic infection and retention of LIYV-L2 $\mathrm{C}_{\mathrm{tGFP}}$ cassette was checked by RT-PCR, the 440-nt truncated GFP fragment was mostly retained at 5 wpi, with some smaller amplicons suggesting some loss of insert (Figure 8B). Moreover, immunoblot analysis of total protein from the systemic leaves confirmed LIYV infection and significant downregulation of the GFP protein level in LIYV-L2 $\mathrm{C}_{\mathrm{tGFP}}$ infected plants compared to LIYV-WT and mock inoculated plants (Figure 8B). 
A.
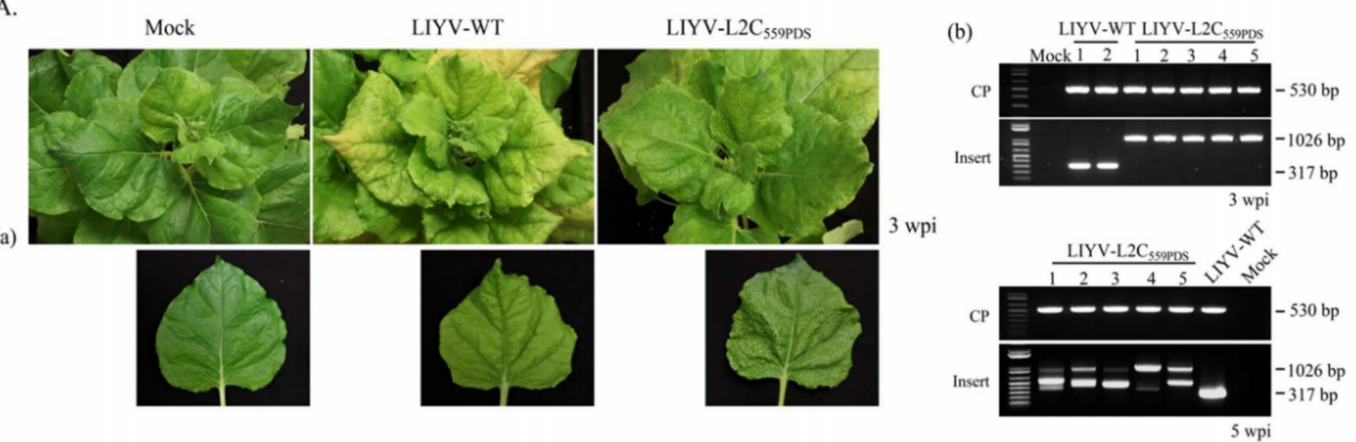

B.
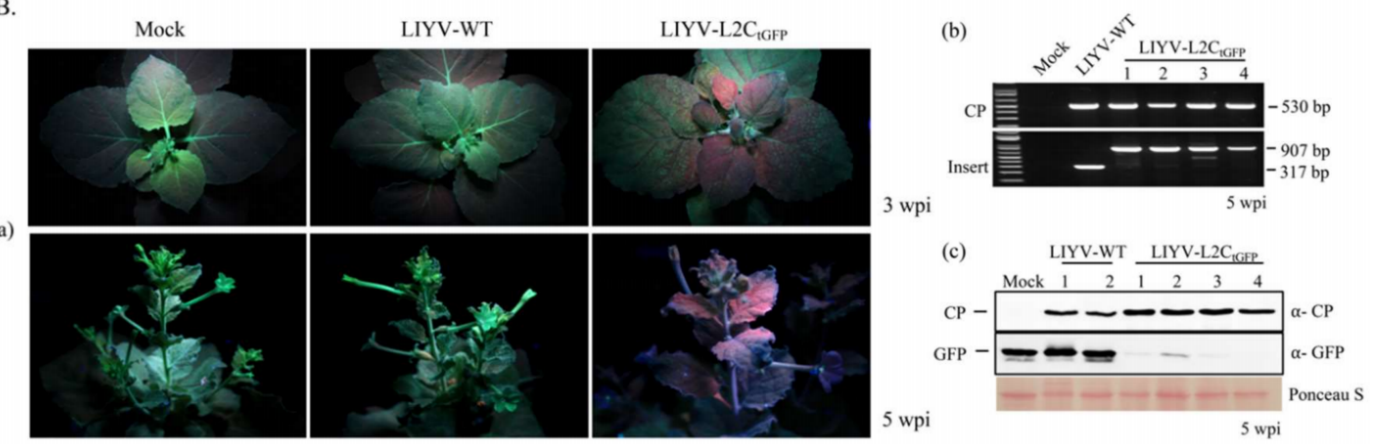

Figure 8. Virus-induced gene silencing in plants infected with LIYV vectors. (A) Silencing of the phytoene desaturase (PDS) gene with LIYV-L2 $\mathrm{C}_{\mathrm{tPDS}}$ in Hc-Pro transgenic N. benthamiana plants. (a) Phenotypes of LIYV-WT and LIYV-L2 $\mathrm{C}_{\mathrm{tPDS}}$ infected N. benthamiana plants photographed at 3 wpi; (b) Detection of viral infection and insertion integrity by RT-PCR with total RNA extracted from upper non-inoculated leaves at 3 wpi and 5 wpi. Two primer sets were used to amplify the sequence of LIYV CP (CP, $530 \mathrm{bp}$ ) and the truncated PDS cassette (Insert, $1026 \mathrm{bp}$ ), LIYV-WT without the insert was amplified as a control ( $317 \mathrm{bp})$. The bands in between at 5 wpi indicate partial deletions of the inserted cassette. (B) Silencing of GFP transgene with LIYV-L2C $\mathrm{CGFP}_{\mathrm{tG}}$ in $16 \mathrm{c}$ transgenic N. benthamiana plants. (a) Silencing effects of LIYV-L2CtGFP observed under UV light at 3 wpi and 5 wpi. Plants inoculated with buffer (Mock) and LIYV-WT were negative controls; (b) Viral infection and insertion integrity were assessed by RT-PCR with total RNA extracted from upper non-inoculated leaves at 5 wpi. Two primer sets were used to amplify the sequence of LIYV CP (CP, $530 \mathrm{bp})$ and the truncated GFP cassette (Insert, 907 bp); (c) Immunoblot analysis of LIYV CP and GFP accumulation in upper non-inoculated leaves of LIYV-WT and LIYV-L2 $\mathrm{C}_{\mathrm{tGFP}}$ infected plants using LIYV CP and GFP specific antibodies. The Ponceau S stained Rubisco large subunit serves as a loading control.

\section{Discussion}

The family Closteroviridae includes four genera: Closterovirus, Crinivirus, Ampelovirus and Velarivirus. All viruses in this family have filamentous rod-shaped virions and posseses the largest genomes of plant-infecting positive-sense single-stranded RNA viruses. Their large, complex genomes and because they infect several economically important crop plants such as citrus, grapevines and cucurbits have drawn interest to develop closterovirus-based vectors for both fundamental and practical applications. So far, BYV, Citrus tristeza virus (CTV), and Grapevine leafroll-associated virus 2 (GLRaV-2), all members of the genus Closterovirus, have been developed into efficient gene expression vectors capable of infecting their host plants systemically and exhibiting strong potential for application in functional genomics and possibly pest and/or pathogen control [44-46]. However, until the present work no crinivirus-derived vector has yet been available. Criniviruses have genomes that are bipartite in contrast to the monopartite genome of viruses in other genera of the family Closteroviridae [47]. The genomic RNAs are separately encapsidated into virions approximately half the length of the virions seen for monopartite viruses of the genus Closterovirus. Could criniviruses have advantages 
over closterovirus-based vectors? Can sequences be inserted into both of the genomic RNAs? Can the recombinant viruses retain insect vector transmissibility and induce desired effects in different host plant species? In this study we addressed some of these questions. We developed a crinivirus-derived vector using LIYV, which is capable of systemic infection for efficient protein expression and VIGS in different plant species. This can be delivered by agroinoculation to N. benthamiana plants, and by whitefly transmission to other species that are recalcitrant to agroinoculation. This LIYV vector thus provides a valuable tool for studying plant-microbe interactions, functional genomics, and possibly even approaches for pest and/or pathogen control.

The first successfully developed closterovirus vector, BYV, was constructed through the "add-a-gene" strategy, that involved the splicing of an autonomous cassette controlled by an additional sgRNA CE, and this has become a prototype for other closterovirus-based vectors [45,46,48]. Based on the properties of closteroviruses that the sgRNAs for ORFs closer to the $3^{\prime}$ terminus of the genome tend to accumulate to higher levels [49], we inserted the GFP reporter cassette separately in between the last ORF and 3'-NTR of clones for both LIYV genomic RNAs. However, bright fluorescence was only observed with the RNA2 construct and fluorescence was limited to phloem tissues and was strongest in leaves with viral symptom development. LIYV accumulation, as determined by immunoblot analysis for the $\mathrm{CP}$, indicated lower amounts of CP compared to wildtype virus, likely because of the increased genome size and the additional promoter [50]. The infectivity of the RNA1 construct was abolished when the GFP cassette was inserted near the RNA $13^{\prime}$ region. Considering that LIYV RNA1 encodes proteins critical for virus replication, the addition of the exogenous gene may have disrupted some of its necessary functions.

Another common strategy to express foreign genes from a viral vector is to replace part of the virus genome that encodes a non-essential protein. Based on our knowledge of LIYV, the appropriate functions of all genes are essential for efficient systemic infection, but mutations of either P5 or P9 genes only results in reduced virus accumulation without disrupting the systemic infectivity of LIYV in N. benthamiana plants [22]. The P5 ORF was therefore replaced by the GFP ORF to test the possibility of constructing a LIYV vector through the "substitution" strategy. Not surprisingly, the substituted LIYV vector was capable of systemic GFP expression in N. benthamiana plants, but at a much-reduced efficiency compared to the "add-a-gene" construct. This might be because P5 is the only LIYV-encoded protein that is translated from the full-length RNA2, and full-length RNA2 also must become encapsidated for progeny virion accumulation, as well as the lack of possible P5 functions on viral infection.

Of the closterovirus expression vectors examined previously, the choice of an appropriate CE is important and can affect the efficiency of foreign gene expression. The CP sgRNA CE directs gene expression and to a high level and is often employed to drive foreign gene expression [50]. Empirically, addition of a duplicated sequence in viral genomes increases its risk of being eliminated via homologous recombination, i.e., reduces vector stability [51]. Therefore, a heterologous $\mathrm{CP}$ sgRNA CE from a related virus has been commonly introduced for constructing closterovirus-derived vectors $[40,45,46,48]$. However, CTV vectors exhibited high tolerance to the duplicated homologous sequence, the extra gene controlled by a homologous or heterologous CP sgRNA CE showed no obvious effect on the expression level and stability of CTV construct [46]. Similar to CTV vectors, the GFP expression cassette driven by a duplicated LIYV CE showed high protein expression and genome stability. Surprisingly, when we replaced LIYV CP sgRNA CE with that of another crinivirus, CYSDV, a similar virus accumulation level and retention of the intact expression cassette were detected systemically, but no GFP expression was obtained. The activity of the heterologous CYSDV CE might have been inhibited without its natural genetic background, thus might represent viral specificity in the generation of the subgenomic RNAs. Moreover, when BYV CP sgRNA CE was used, no sign of LIYV infection was detected in the agroinoculated plants. It is yet unclear how the added BYV CE abolished LIYV infectivity, but may indicate low tolerance of criniviruses to foreign functional elements. 
The effect of different sizes of the LIYV CE was also examined for optimal expression, since the LIYV sgRNA CE has not been characterized and an arbitrary sequence was selected for the first trials. Unlike that observed with the heterologous BYV sgRNA CE used in CTV vectors, in which no clear relationship was found between the size of the CE and gene expression [46], the longer CE used in the LIYV vector was shown to be preferable for higher GFP expression, but lower virus accumulation. Furthermore, the capacity of LIYV vector to express large inserts was tested by expressing the $\sim 2 \mathrm{~kb}$ GUS gene. Instability of the insertion was noticed over time; however, good GUS activity was continuously produced at the very late stage of the infected $N$. benthamiana plants. This shows the ability of LIYV to harbor and express a large gene, but it is not as stable as some other closterovirus vectors such as GLRaV-2 and CTV that have demonstrated the ability to accommodate a gene of similar size stably over a year in their host plants [36,45].

The ability of LIYV vectors for VIGS was validated by silencing the endogenous gene PDS in Hc-Pro transgenic N. benthamiana plants, and the transgene GFP in N. benthamiana line 16c plants. The photo-bleaching phenotype was observed continuously in the veins of Hc-Pro N. benthamiana plants infected with LIYV vector harboring a truncated PDS fragment. It is interesting to note the efficiency of the LIYV VIGS vector induced silencing in the Hc-Pro N. benthamiana plants as these plants constitutively express Hc-Pro, a potent suppressor of RNAi activity. The Hc-Pro silencing suppressor has been reported previously to suppress VIGS [52], but LIYV induced VIGS was unaffected in the vascular tissues. By contrast, a strong silencing effect was visualized with the GFP construct starting from the vascular system then expanding to other areas, which is consistent with the cell-to-cell and systemic transport of RNAi signal described before [53].

The LIYV-based vectors developed here have exhibited a dual capacity for recombinant gene expression in the phloem, and for systemic silencing targeting endogenous host genes and transgenes in $N$. benthamiana plants. When combined with the ability of being transmitted by whitefly vectors and the wide host range of LIYV, LIYV-based vectors can be a valuable research tool, especially for research relevant to the vascular system. It also provides a model that could be applicable to other economically important criniviruses and their specific host plants.

Author Contributions: Wenjie Qiao and Bryce W. Falk conceived and designed the experiments; Wenjie Qiao performed the experiments; Wenjie Qiao and Bryce W. Falk wrote the paper.

Acknowledgments: This work was supported by Jastro-Shields research awards to Wenjie Qiao, and by the University of California. We have not received funds to cover costs to publish in open access.

Conflicts of Interest: The authors declare no conflict of interest.

\section{References}

1. Ferriol, I.; Turina, M.; Zamora-Macorra, E.; Falk, B. RNA1-independent replication and GFP expression from Tomato marchitez virus isolate M cloned cDNA. Phytopathology 2016, 106, 500-509. [CrossRef] [PubMed]

2. Lazareva, E.A.; Lezzhov, A.A.; Komarova, T.V.; Morozov, S.Y.; Heinlein, M.; Solovyev, A.G. A novel block of plant virus movement genes. Mol. Plant Pathol. 2017, 18, 611-624. [CrossRef] [PubMed]

3. Boissinot, S.; Pichon, E.; Sorin, C.; Piccini, C.; Scheidecker, D.; Ziegler-Graff, V.; Brault, V. Systemic propagation of a fluorescent infectious clone of a polerovirus following inoculation by agrobacteria and aphids. Viruses 2017, 9, 166. [CrossRef] [PubMed]

4. Lu, R.; Malcuit, I.; Moffett, P.; Ruiz, M.T.; Peart, J.; Wu, A.J.; Rathjen, J.P.; Bendahmane, A.; Day, L.; Baulcombe, D.C. High throughput virus-induced gene silencing implicates heat shock protein 90 in plant disease resistance. EMBO J. 2003, 22, 5690-5699. [CrossRef] [PubMed]

5. Constantin, G.D.; Krath, B.N.; MacFarlane, S.A.; Nicolaisen, M.; Elisabeth Johansen, I.; Lund, O.S. Virus-induced gene silencing as a tool for functional genomics in a legume species. Plant. J. 2004, 40, 622-631. [CrossRef] [PubMed]

6. Ratcliff, F.; Martin-Hernandez, A.M.; Baulcombe, D.C. Technical advance: Tobacco rattle virus as a vector for analysis of gene function by silencing. Plant. J. 2001, 25, 237-245. [CrossRef] [PubMed] 
7. Lee, W.-S.; Hammond-Kosack, K.E.; Kanyuka, K. Barley stripe mosaic virus-mediated tools for investigating gene function in cereal plants and their pathogens: Virus-induced gene silencing, host-mediated gene silencing, and virus-mediated overexpression of heterologous protein. Plant. Physiol. 2012, 160, 582-590. [CrossRef] [PubMed]

8. Khan, A.M.; Ashfaq, M.; Kiss, Z.; Khan, A.A.; Mansoor, S.; Falk, B.W. Use of recombinant tobacco mosaic virus to achieve RNA interference in plants against the citrus mealybug, Planococcus citri (Hemiptera: Pseudococcidae). PLoS ONE 2013, 8, e73657. [CrossRef] [PubMed]

9. Hajeri, S.; Killiny, N.; El-Mohtar, C.; Dawson, W.O.; Gowda, S. Citrus tristeza virus-based RNAi in citrus plants induces gene silencing in Diaphorina citri, a phloem-sap sucking insect vector of citrus greening disease (Huanglongbing). J. Biotechnol. 2014, 176, 42-49. [CrossRef] [PubMed]

10. Wang, J.; Turina, M.; Stewart, L.R.; Lindbo, J.A.; Falk, B.W. Agroinoculation of the crinivirus, lettuce infectious yellows virus, for systemic plant infection. Virology 2009, 392, 131-136. [CrossRef] [PubMed]

11. Khan, A.M.; Ashfaq, M.; Khan, A.A.; Rasool, A.; Iqbal, J.; Mansoor, S. Inoculation of Nicotiana tabacum with recombinant potato virus $\mathrm{X}$ induces RNA interference in the solenopsis mealybug, Phenacoccus solenopsis Tinsley (Hemiptera: Pseudococcidae). Biotechnol. Lett. 2015, 37, 2083-2090. [CrossRef] [PubMed]

12. Kolliopoulou, A.; Taning, C.N.; Smagghe, G.; Swevers, L. Viral delivery of dsRNA for control of insect agricultural pests and vectors of human disease: Prospects and challenges. Front. Physiol. 2017, 8, 399. [CrossRef] [PubMed]

13. Hefferon, K.L. Plant virus expression vectors set the stage as production platforms for biopharmaceutical proteins. Virology 2012, 433, 1-6. [CrossRef] [PubMed]

14. Roy, G.; Weisburg, S.; Rabindran, S.; Yusibov, V. A novel two-component tobacco mosaic virus-based vector system for high-level expression of multiple therapeutic proteins including a human monoclonal antibody in plants. Virology 2010, 405, 93-99. [CrossRef] [PubMed]

15. Chen, T.-H.; Hu, C.-C.; Liao, J.-T.; Lee, Y.-L.; Huang, Y.-W.; Lin, N.-S.; Lin, Y.-L.; Hsu, Y.-H. Production of Japanese encephalitis virus antigens in plants using bamboo mosaic virus-based vector. Front. Microbiol. 2017, 8, 788. [CrossRef] [PubMed]

16. Starkevič, U.; Bortesi, L.; Virgailis, M.; Ružauskas, M.; Giritch, A.; Ražanskienė, A. High-yield production of a functional bacteriophage lysin with antipneumococcal activity using a plant virus-based expression system. J. Biotechnol. 2015, 200, 10-16. [CrossRef] [PubMed]

17. Hefferon, K. Plant virus expression vector development: New perspectives. BioMed Res. Int. 2014. [CrossRef] [PubMed]

18. Kawai, T.; Gonoi, A.; Nitta, M.; Yamagishi, N.; Yoshikawa, N.; Tao, R. Virus-induced gene silencing in various Prunus species with the apple latent spherical virus vector. Sci. Hortic. 2016, 199, 103-113. [CrossRef]

19. Zhao, F.; Lim, S.; Igori, D.; Yoo, R.H.; Kwon, S.-Y.; Moon, J.S. Development of tobacco ringspot virus-based vectors for foreign gene expression and virus-induced gene silencing in a variety of plants. Virology 2016, 492, 166-178. [CrossRef] [PubMed]

20. Lim, S.; Nam, M.; Kim, K.H.; Lee, S.-H.; Moon, J.-K.; Lim, H.-S.; Choung, M.-G.; Kim, S.-M.; Moon, J.S. Development of a new vector using soybean yellow common mosaic virus for gene function study or heterologous protein expression in soybeans. J. Virol. Methods 2016, 228, 1-9. [CrossRef] [PubMed]

21. Tzanetakis, I.E.; Martin, R.R.; Wintermantel, W.M. Epidemiology of criniviruses: An emerging problem in world agriculture. Front. Microbiol. 2013, 4, 119. [CrossRef] [PubMed]

22. Kiss, Z.A.; Medina, V.; Falk, B.W. Crinivirus replication and host interactions. Front. Microbiol. 2013,4 , 99. [CrossRef] [PubMed]

23. Yeh, H.H.; Tian, T.; Rubio, L.; Crawford, B.; Falk, B.W. Asynchronous accumulation of lettuce infectious yellows virus RNAs 1 and 2 and identification of an RNA 1 trans enhancer of RNA 2 accumulation. J Virol. 2000, 74, 5762-5768. [CrossRef] [PubMed]

24. Wang, J.; Stewart, L.R.; Kiss, Z.; Falk, B.W. Lettuce infectious yellows virus (LIYV) RNA 1-encoded P34 is an RNA-binding protein and exhibits perinuclear localization. Virology 2010, 403, 67-77. [CrossRef] [PubMed]

25. Tian, T.; Rubio, L.; Yeh, H.H.; Crawford, B.; Falk, B.W. Lettuce infectious yellows virus: In vitro acquisition analysis using partially purified virions and the whitefly Bemisia tabaci. J. Gen. Virol. 1999, 80, 1111-1117. [CrossRef] [PubMed] 
26. Stewart, L.R.; Medina, V.; Tian, T.; Turina, M.; Falk, B.W.; Ng, J.C. A mutation in the lettuce infectious yellows virus minor coat protein disrupts whitefly transmission but not in planta systemic movement. J. Virol. 2010, 84, 12165-12173. [CrossRef] [PubMed]

27. Stewart, L.R.; Medina, V.; Sudarshana, M.R.; Falk, B.W. Lettuce infectious yellows virus-encoded P26 induces plasmalemma deposit cytopathology. Virology 2009, 388, 212-220. [CrossRef] [PubMed]

28. Rubio, L.; Tian, T.; Yeh, H.H.; Livieratos, Y.; Falk, B.W. De novo generation of lettuce infectious yellows virus defective RNAs in protoplasts. Mol. Plant. Pathol 2002, 3, 321-327. [CrossRef] [PubMed]

29. Gowda, S.; Satyanarayana, T.; Ayllón, M.A.; Albiach-Martı, M.R.; Mawassi, M.; Rabindran, S.; Garnsey, S.M.; Dawson, W.O. Characterization of the cis-acting elements controlling subgenomic mRNAs of Citrus tristeza virus: Production of positive-and negative-stranded 3'-terminal and positive-stranded 5'-terminal RNAs. Virology 2001, 286, 134-151. [CrossRef] [PubMed]

30. Baulcombe, D.C. Fast forward genetics based on virus-induced gene silencing. Curr. Opin. Plant Biol. 1999, 2, 109-113. [CrossRef]

31. Dinesh-Kumar, S.; Anandalakshmi, R.; Marathe, R.; Schiff, M.; Liu, Y. Virus-induced gene silencing. In Plant Functional Genomics; Springer: Berlin/Heidelberg, Germany, 2003; pp. 287-293.

32. Hannon, G.J. RNA interference. Nature 2002, 418, 244. [CrossRef] [PubMed]

33. Ruiz, M.T.; Voinnet, O.; Baulcombe, D.C. Initiation and maintenance of virus-induced gene silencing. Plant Cell 1998, 10, 937-946. [CrossRef] [PubMed]

34. Fukuda, H.; Arai, M.; Kuwajima, K. Folding of green fluorescent protein and the cycle3 mutant. Biochemistry 2000, 39, 12025-12032. [CrossRef] [PubMed]

35. Heim, R.; Tsien, R.Y. Engineering green fluorescent protein for improved brightness, longer wavelengths and fluorescence resonance energy transfer. Curr. Biol. 1996, 6, 178-182. [CrossRef]

36. El-Mohtar, C.; Dawson, W.O. Exploring the limits of vector construction based on Citrus tristeza virus. Virology 2014, 448, 274-283. [CrossRef] [PubMed]

37. Klaassen, V.A.; Boeshore, M.; Dolja, V.V.; Falk, B.W. Partial characterization of the lettuce infectious yellows virus genomic RNAs, identification of the coat protein gene and comparison of its amino acid sequence with those of other filamentous RNA plant viruses. J. Gen. Virol. 1994, 75, 1525-1533. [CrossRef] [PubMed]

38. Klaassen, V.A.; Mayhew, D.; Fisher, D.; Falk, B.W. In vitro transcripts from cloned cDNAs of the lettuce infectious yellows closterovirus bipartite genomic RNAs are competent for replication in Nicotiana benthamiana protoplasts. Virology 1996, 222, 169-175. [CrossRef] [PubMed]

39. Lagarde, D.; Basset, M.; Lepetit, M.; Conejero, G.; Gaymard, F.; Astruc, S.; Grignon, C. Tissue-specific expression of Arabidopsis AKT1 gene is consistent with a role in K+ nutrition. Plant J. 1996, 9, 195-203. [CrossRef] [PubMed]

40. Dolja, V.V.; Koonin, E.V. The closterovirus-derived gene expression and RNA interference vectors as tools for research and plant biotechnology. Front. Microbiol. 2013, 4, 83. [CrossRef] [PubMed]

41. Dawson, W.; Lewandowski, D.; Hilf, M.; Bubrick, P.; Raffo, A.; Shaw, J.; Grantham, G.; Desjardins, P. A tobacco mosaic virus-hybrid expresses and loses an added gene. Virology 1989, 172, 285-292. [CrossRef]

42. Sarkies, P.; Miska, E.A. Small RNAs break out: The molecular cell biology of mobile small RNAs. Nat. Rev. Mol. Cell. Biol. 2014, 15, 525-535. [CrossRef] [PubMed]

43. Molnar, A.; Melnyk, C.W.; Bassett, A.; Hardcastle, T.J.; Dunn, R.; Baulcombe, D.C. Small silencing RNAs in plants are mobile and direct epigenetic modification in recipient cells. Science 2010, 328, 872-875. [CrossRef] [PubMed]

44. Ambrós, S.; El-Mohtar, C.; Ruiz-Ruiz, S.; Peña, L.; Guerri, J.; Dawson, W.O.; Moreno, P. Agroinoculation of Citrus tristeza virus causes systemic infection and symptoms in the presumed nonhost Nicotiana benthamiana. Mol. Plant. Microbe Interact. 2011, 24, 1119-1131. [CrossRef] [PubMed]

45. Kurth, E.G.; Peremyslov, V.V.; Prokhnevsky, A.I.; Kasschau, K.D.; Miller, M.; Carrington, J.C.; Dolja, V.V. Virus-derived gene expression and RNA interference vector for grapevine. J. Virol. 2012, 86, 6002-6009. [CrossRef] [PubMed]

46. Folimonov, A.S.; Folimonova, S.Y.; Bar-Joseph, M.; Dawson, W.O. A stable RNA virus-based vector for citrus trees. Virology 2007, 368, 205-216. [CrossRef] [PubMed]

47. Qiao, W.; Medina, V.; Falk, B.W. Inspirations on virus replication and cell-to-cell movement from studies examining the cytopathology induced by lettuce infectious yellows virus in plant cells. Front. Plant. Sci. 2017, 8, 1672. [CrossRef] [PubMed] 
48. Peremyslov, V.V.; Hagiwara, Y.; Dolja, V.V. HSP70 homolog functions in cell-to-cell movement of a plant virus. Proc. Natl. Acad. Sci. USA 1999, 96, 14771-14776. [CrossRef] [PubMed]

49. Navas-Castillo, J.; Albiach-Martí, M.R.; Gowda, S.; Hilf, M.E.; Garnsey, S.M.; Dawson, W.O. Kinetics of accumulation of citrus tristeza virus RNAs. Virology 1997, 228, 92-97. [CrossRef] [PubMed]

50. Hagiwara, Y.; Peremyslov, V.V.; Dolja, V.V. Regulation of closterovirus gene expression examined by insertion of a self-processing reporter and by northern hybridization. J. Virol. 1999, 73, 7988-7993. [PubMed]

51. Donson, J.; Kearney, C.; Hilf, M.; Dawson, W. Systemic expression of a bacterial gene by a tobacco mosaic virus-based vector. Proc. Natl. Acad. Sci. USA 1991, 88, 7204-7208. [CrossRef] [PubMed]

52. Anandalakshmi, R.; Pruss, G.J.; Ge, X.; Marathe, R.; Mallory, A.C.; Smith, T.H.; Vance, V.B. A viral suppressor of gene silencing in plants. Proc. Natl. Acad. Sci. USA 1998, 95, 13079-13084. [CrossRef] [PubMed]

53. Dunoyer, P.; Schott, G.; Himber, C.; Meyer, D.; Takeda, A.; Carrington, J.C.; Voinnet, O. Small RNA duplexes function as mobile silencing signals between plant cells. Science 2010, 328, 912-916. [CrossRef] [PubMed]

(C) 2018 by the authors. Licensee MDPI, Basel, Switzerland. This article is an open access article distributed under the terms and conditions of the Creative Commons Attribution (CC BY) license (http:/ / creativecommons.org/licenses/by/4.0/). 